\title{
In Vitro Fermentation Characteristics of Camelina Meal Comparison with Soybean Meal
}

\author{
Ozge SIZMAZ ${ }^{1, *}\left(\mathbb{D}\right.$, Ali CALIK ${ }^{1}\left(\mathbb{D}\right.$, Atakan BUNDUR $^{1}$ \\ ${ }^{1}$ Ankara University, Faculty of Veterinary Medicine, Department of Animal Nutrition and Nutritional Diseases, Ankara, \\ Turkey. \\ *Corresponding author
}

\section{Article History}

Received: 16 February 2021

Accepted: 11 April 2021

First Online: 18 April 2021

\section{Corresponding Author}

E-mail: ozgeabacioglu@gmail.com

\section{Keywords}

Alternative protein sources

In vitro gas production

Methane

\begin{abstract}
The search for new and cheap sources of protein has been increased lately. Although camelina meal has antinutritive factors; compare to soybean it can be widely useable. The objective of this study is to remove the question mark in minds about camelina meal and to determine the fermentation characteristics parameters including $\mathrm{pH}$, ammonia- $\mathrm{N}$ level, volatile fatty acids concentration as well as total gas volume, methane proportion and the estimated degradation of camelina meal in comparison with soybean meal. Basically, we used in vitro gas production system according to modified Hohenheim Gas Test (HFT) to compare camelina meal and soybean meal. Rumen contents obtained from two Holstein cows. There was no significant difference of $\mathrm{pH}$ and ammonia- $\mathrm{N}$ concentration between soybean meal and camelina meal, whereas total volatile fatty acid and acetate concentration were reduced in camelina meal. Additionally, total gas production, fermentative $\mathrm{CO}_{2}$ and estimated ME and organic matter digestibility were not altered. However, methane production decreased significantly in camelina meal fermenters. Consequently, it was concluded that camelina meal can be replaced of soybean meal, since microbial fermentation does not change and it might reduce the methane emission in which has commonly major effect on environmental pollution as a sera gas.
\end{abstract}

\section{Introduction}

Soybean meal (SBM) is commonly used in livestock nutrition as an attractive protein source of plant origin in the world, although its high price. In ruminants that costs don't compete with the humans or monogastric animals have encouraged the search alternative protein sources to replace soybean meal (Haddad, 2006; Alves et al., 2016; Florou-Paneri et al., 2014). In the last decades, due to its high quality protein and the search for cheaper resources, the demand for camelina seeds has increased (Russo et al., 2017). Camelina sativa compared to soybean has low nutrient requirements, good resistance to diseases and pests (HalmemiesBeauchet-Filleau et al., 2018). Camelina meal (CM), the by-product of camelina oil extraction, is an alternative protein source for livestock despite its higher antinutritive factors compared to soybean meal (Sizmaz et al., 2016; Russo et al., 2017). Nevertheless, CM has been considered as acceptable (Waraich et al., 2013). $\mathrm{CM}$ in livestock diets contain glucosinolates, phytic acid, sinapine and condensed tannins. Especially glucosinolates are antinutritional factors; disrupts the thyroid activity and decreases the feed intake (Paula et al., 2019). Therefore, in 2002, European Union (EU) Directive forbid the usage of $C$. sativa in livestock rations due to the presence of glucosinolates. Yet, in $2008 \mathrm{EU}$ Directive, after many studies, permits the feed use of $C$. sativa and its derivatives (Colombini et al., 2014). Because ruminants are more tolerant to glucosinolates compared to monogastric animals; is also a reason to put them back in the field (Vincent et al., 1988).

We hypothesized that the camelina meal might be shown similar fermentation characteristics with soybean meal. Thus, the current study is conducted to investigate the in vitro rumen fermentation parameters including $\mathrm{pH}$, ammonia- $\mathrm{N}$ level, volatile fatty acid concentration, estimated degradation and gas 
production of camelina meal as a replacement of soybean meal.

\section{Materials and Methods}

Based on our previous study (Sizmaz et al., 2016), evaluating the impact of nutrients degradation of camelina and soybean meal in vitro, the fermentation characteristics, gas production and fermentative methane emission were investigated in this study. The same camelina meal and soybean meal samples were used in this experiment. Thereby the nutrients of the samples were taken from our previous study (Table 1).

\section{In Vitro Fermentation Technique}

In vitro rumen fermentation was performed according to a modified HFT (Menke and Steingass, 1986). Two hundred milligrams of the camelina meal and soybean meal substrate were incubated with $30 \mathrm{ml}$ of a ruminal buffered suspension (2:1; buffer solution: rumen fluid) by flushing $\mathrm{CO}_{2}$ before was anaerobically dispensed in each syringe at $39^{\circ} \mathrm{C}$. The rumen contents were obtained from two cannulated Holstein cows with a live weight of $630 \pm 21.3 \mathrm{~kg}$ before morning feeding kept at Ministry of Agriculture and Forestry, International Center for Livestock Research and Training. Rumen fluid was immediately transferred to the laboratory to in vitro fermentation with preheated thermos flask. Then, rumen fluid immediately mixed with the buffer solution (Macro Element Solution: $\mathrm{Na}_{2} \mathrm{HPO}_{4}, \mathrm{KH}_{2} \mathrm{PO}_{4}$ and $\mathrm{MgSO}_{4} .7 \mathrm{H}_{2} \mathrm{O}$; Micro Element Solution: $\mathrm{CaCl}_{2} .2 \mathrm{H}_{2} \mathrm{O}, \mathrm{MnCl}_{2} .4 \mathrm{H}_{2} \mathrm{O}, \mathrm{CoCl}_{2} .6 \mathrm{H}_{2} \mathrm{O}$ and $\mathrm{FeCl}_{3} .6 \mathrm{H}_{2} \mathrm{O}$; Buffer Solution $=\mathrm{NaHCO}_{3}$ and $\mathrm{NH}_{4} \mathrm{HCO}_{3}$; Resazurin Solution=Resazurin; Reductant Solution= $\mathrm{Na}_{2} \mathrm{~S} .7 \mathrm{H}_{2} \mathrm{O}$ and $\mathrm{NaOH}$ ) which was bubbled with $\mathrm{CO}_{2}$, at $39^{\circ} \mathrm{C}$ for $24 \mathrm{~h}$ incubation.

\section{Rumen Sampling and Analysis}

After $24 \mathrm{~h}$ incubation, the rumen fluid samples were collected from syringes of each group and were strained into the individual beakers with a sterile cheesecloth to stop the fermentation. The $\mathrm{pH}$ was measured immediately with a pH-meter (Hanna Instruments). Ammonia- $\mathrm{N}$ in rumen fluid was analyzed using spectrophotometry by using indophenol blue method at $546 \mathrm{~nm}$ according to the method described by Chaney and Marbach (1962).

Concentration of VFA were determined according to Geissler et al. (1976). Rumen samples were centrifuged at $4.000 \mathrm{rpm}$ for $15 \mathrm{~min}$ at $4^{\circ} \mathrm{C}$. One $\mathrm{ml}$ of supernatant was then transferred to an Eppendorf tube and mixed with $0.2 \mathrm{ml}$ ice-cold $25 \%$ met phosphoric acid solution. Then, tubes were kept at $4^{\circ} \mathrm{C}$ for $30 \mathrm{~min}$. Subsequently, these tubes were centrifuged again at $13.000 \mathrm{rpm}$ for $10 \mathrm{~min}$ at $4^{\circ} \mathrm{C}$ and the supernatant was transferred into gas chromatography vials to determine acetic acid, propionic acid, butyric acid, isobutyric acid, valeric acid and isovaleric acid concentrations. Samples were analyzed by using gas chromatography (Shimadzu GC-2010, Shimadzu Co., Kyoto, Japan) coupled with a capillary column (TR-151035, TRB-FFAP, $30 \mathrm{~m} \times 0.53$ $\mathrm{mm}$ ). The column temperature was programmed to increase gradually from $120^{\circ} \mathrm{C}$ to $160^{\circ} \mathrm{C}$ during the analysis. In addition, the injector port and flame ionization detector (FID) temperatures were fixed at $230^{\circ} \mathrm{C}$ and $250^{\circ} \mathrm{C}$, respectively. The injection volume was set to $1 \mu \mathrm{L}$ and analyses were performed in duplicate.

\section{In Vitro Total Gas Volume, Methane Production and Estimated Digestion Values}

After $24 \mathrm{~h}$ of incubation, the total gas volume of each syringe was recorded. The metabolizable energy (ME) and organic matter digestibility (DOM) contents of the camelina meal and soybean meal were calculated using the equations by Menke and Steingass (1988) as follows:

$$
\begin{aligned}
& \mathrm{ME}(\mathrm{MJ} / \mathrm{kg})=2.20+0.136 \times \mathrm{Gas} 24 \mathrm{~h}+0.057 \times \mathrm{CP} \\
& \mathrm{DOM}(\mathrm{g} / \mathrm{kg})=14.88+0.889 \times \mathrm{Gas} 24 \mathrm{~h}+0.45 \times \mathrm{CP}+ \\
& 0.0651 \times \mathrm{A}
\end{aligned}
$$

Where; Gas24 h net gas production ( $\mathrm{ml} / 200 \mathrm{mg}$ ), $\mathrm{CP}$; crude protein (\%), A; ash content (\%).

Methane production was calculated using the equations proposed by Abdl-Rahman (2010) based on the stoichiometry of Wolin (1960), as follows;

$$
\text { Fermentative } \mathrm{CO}_{2}=\mathrm{A} / 2+\mathrm{P} / 4+1.5 \mathrm{~B}
$$$$
\text { Fermentative } \mathrm{CH}_{4}=(\mathrm{A}+2 \mathrm{~B})-\mathrm{CO}_{2}
$$

A; mole of acetate, $\mathrm{P}$; mole of propionate, $\mathrm{B}$; mole of butyrate.

Table 1. The chemical composition of camelina meal and soybean meal used in the experiment.

\begin{tabular}{lll}
\hline Chemical Composition & Soybean Meal & Camelina Meal \\
\hline DM & 896.00 & 885.90 \\
OM & 940.00 & 946.10 \\
CP & 482.00 & 369.70 \\
EE & 16.50 & 14.90 \\
CF & 52.50 & 110.70 \\
Ash & 60.00 & 53.90 \\
ME, MJ/kg & 11.67 & 10.40 \\
\hline
\end{tabular}

DM; Drv matter, OM; organic matter, CP; crude protein, EE; ether extract, CF; crude fiber, ME; metabolizable energv. 


\section{Statistical Analysis}

Statistical analysis for the data from the rumen fermentation parameters were conducted using SPSS software (V22.0; SPSS Inc., Chicago, IL, USA). First, the Shapiro-Wilk test was adopted to check whether the distribution of the variables exhibited a normal distribution. Then, the variables that showed a normal distribution were analyzed by the independent sample $t$ test. Significant differences were declared at $\mathrm{P}<0.05$; a tendency was considered for $0.05<\mathrm{P} \leq 0.10$.

\section{Results}

The in vitro fermentation characteristics of the soybean meal and camelina meal are shown in Table 2. Basically, after the results from in vitro fermentation; the levels of acetate and total VFA are significantly higher in soybean meal than CM $(P<0.05)$. Additionally, as it can be seen in the Table 2 the level of isovalerate and propionate tended to increase in soybean meal than $\mathrm{CM}(0.05<\mathrm{P} \leq 0.10)$. Soybean meal's $\mathrm{pH}$ level were higher than $\mathrm{CM}$ numerically (6.92 vs. 6.79). However, as for $A / P$, isobutyrate, butyrate, isovalorate and valorate levels; no significant difference was observed between soybean meal and CM ( $P>0.05)$.

The in vitro total gas volume, fermentative $\mathrm{CH}_{4}$ fermentative $\mathrm{CO}_{2}$ and estimated digestibility of camelina meal and soybean meal are shown in Table 3. Initially the level of fermentative $\mathrm{CH}_{4}$ is significantly higher in soybean meal than $\mathrm{CM}(\mathrm{P}<0.05)$. However, there were no differences determined in the fermentative $\mathrm{CO}_{2}$, total gas volume, ME and DOM between soybean meal and $\mathrm{CM}(\mathrm{P}>0.05)$.

\section{Discussion}

In the recent years, camelina meal has been evaluated for alternative protein sources in ruminant rations. Plenty of studies have shown the potential of camelina meal to improve the degradability and few of them to modify ruminal fermentation (Moriel et al., 2011; Colombini et al., 2014; Lawrence et al., 2016; Sizmaz et al., 2016 \& Brando et al., 2018). Present study contributes the literatures for an in vitro fermentation characteristics including $\mathrm{pH}$, ammonia level, VFA concentration, total gas volume and methane production of $\mathrm{CM}$ compared to SBM in an in vitro gas production system. Our study provided that $\mathrm{pH}$, ammonia level and VFA were not altered while CM had less concentration of acetate and total VFA. This could be caused by the fiber content of SBM and CM and would be effective in vivo studies. Feeding $\mathrm{CM}$ at $10 \%$ of the diet to heifers did not affect ruminal $\mathrm{pH}$ and ammonia level and volatile fatty acids concentration (Lawrence et al., 2016). Brando et al. (2018) reported that the ruminal $\mathrm{pH}$ and total VFA concentration were not affected by CM treatment at level of $50 \%$ and $100 \%$ in fermentor system. These lack of effects of $\mathrm{CM}$ on ruminal fermentation characteristics may be related to the lack of effects on ruminal microbial population; bacteria, fungi, and protozoa (Bayat et al., 2015; Halmemies-Beauchet-Filleau et al., 2016 \& Paula et al., 2019). Paula et al. (2019) stated that none of the reported studies that tested $\mathrm{CM}$ observed effects on total VFA concentration. Additionally, the study by Lawrence et al. (2016) found that the $\mathrm{NH}_{3}-\mathrm{N}$ levels was higher in CM compared with DDGS and linseed meal fed heifers and Brandao et al. (2018) has shown that the ammonia level decreased by inoculation of $\mathrm{CM}$ to the fermenters. These results associated with the bacterial population and activity, would indicate that the protein degradation in the ration.

Because of the in vitro and in vivo conditions, protein sources, dosage of the $\mathrm{CM}$, the forage:concentrate ratio and basal diet composition, the $\mathrm{CM}$ does not alter on overall microbial fermentation but may effect ruminal milieu as a bacterial community composition and thus change ammonia level and the VFA molar proportions.

Table 2. The in vitro $\mathrm{pH}$, ammonia- $\mathrm{N}(\mathrm{mmol} / \mathrm{l})$ and volatile fatty acids concentration $(\mathrm{mM} / \mathrm{l})$ of camelina meal $(\mathrm{CM})$ and soybean meal (SBM).

\begin{tabular}{|c|c|c|c|c|c|c|c|c|c|c|}
\hline Treatments & $\mathrm{pH}$ & Ammonia-N & $A / P$ & Acetate & Propionate & Isobutyrate & Butyrate & Isovalerate & Valerate & $\begin{array}{l}\text { Total } \\
\text { VFA }\end{array}$ \\
\hline \multirow[t]{2}{*}{ SBM } & $6.92 \pm$ & $41.90 \pm$ & $3.05 \pm$ & $42.91 \pm$ & $14.10 \pm$ & $1.95 \pm$ & $8.17 \pm$ & $3.28 \pm$ & $2.18 \pm$ & $72.58 \pm$ \\
\hline & 0.194 & 3.119 & 0.152 & 1.276 & 0.285 & 0.111 & 0.696 & 0.265 & 0.063 & 0.67 \\
\hline $\mathrm{CM}$ & $\begin{array}{l}6.79 \pm \\
0.147\end{array}$ & $\begin{array}{l}39.04 \pm \\
1.986\end{array}$ & $\begin{array}{l}2.88 \pm \\
0.067\end{array}$ & $\begin{array}{l}35.79 \pm \\
0.883\end{array}$ & $\begin{array}{l}12.47 \pm \\
0.595\end{array}$ & $\begin{array}{l}1.75 \pm \\
0.047\end{array}$ & $\begin{array}{l}7.51 \pm \\
1.125\end{array}$ & $\begin{array}{l}2.59 \pm \\
0.126\end{array}$ & $\begin{array}{l}1.99 \pm \\
0.059\end{array}$ & $\begin{array}{l}62.11 \pm \\
2.489\end{array}$ \\
\hline $\mathrm{P}$ & 0.622 & 0.483 & 0.358 & 0.010 & 0.068 & 0.181 & 0.649 & 0.078 & 0.101 & 0.015 \\
\hline
\end{tabular}

Table 3. The in vitro total gas volume, $\mathrm{CO}_{2}$ and $\mathrm{CH}_{4}$ proportion $(\mathrm{mM} / \mathrm{L})$ and estimated $\mathrm{ME}(\mathrm{MJ} / \mathrm{kg})$ and degradation of organic matter (DOM; $\mathrm{g} / \mathrm{kg}$ ) of camelina meal (CM) and soybean meal (SBM).

\begin{tabular}{llllll}
\hline Treatments & Fermentative $\mathrm{CO}_{2}$ & Fermentative $\mathrm{CH}_{4}$ & Total gas volume & ME & DOM \\
\hline $\mathrm{SBM}$ & $37.23 \pm 0.479$ & $22.01 \pm 0.361$ & $56.67 \pm 17.487$ & $6.49 \pm 0.474$ \\
$\mathrm{CM}$ & $32.28 \pm 2.278$ & $18.54 \pm 0.857$ & $71.33 \pm 32.338$ & $6.25 \pm 0.881$ \\
$\mathrm{P}$ & 0.101 & 0.020 & 0.710 & 0.820 & $44.55 \pm 5.752$ \\
\hline
\end{tabular}


In the present study, we evaluated the decreasing effect of $\mathrm{CM}$ on in vitro methane production. Our best knowledge is this is the first trial of CM effect on methane emission. Some studies have been conducted the effects of camelina oil on total gas volume, $\mathrm{CO}_{2}$ and methane production (Bayat et al., 2015; Ebeid et al., 2020) that reported similar findings with our experiment. In these studies, the authors reported that no difference has been found in the gas volume and $\mathrm{CO}_{2}$ concentration among treatments and a decrease in methane emission in lactating dairy cows fed with different forage:concentrate ratio and camelina oil concentrations and different basal diet compositions such as supplemented with feed additives. Camelina seeds showed the decreasing effect on methane in a ration having a roughage-to-concentrate ratio (Wang et al., 2017). Therefore, the important point the effects on methane emission is the dietary form of camelina if seed, oil or meal used in the diet.

Zagorakis et al. (2015) and Sizmaz et al. (2016) reported that $\mathrm{CM}$ has the potential to substitute SBM, with the protein having relatively low effective degradability compared with that of SBM. Therefore, Hao et al. (2020) reported that the effectiveness of total diet degradation rate of CP was decreased linearly while DOM and gross energy degradation were increased in flax seed meal. On the contrary, in the trial conducted by Salas et al. (2019) the in vitro OM degradation was decreased compared with SBM. According to the study of Brando et al. (2018), the degradation of OM was not affected by supplemented camelina. In the present study the estimated degradation of $\mathrm{ME}$ and $\mathrm{OM}$ were not altered in the treatment groups. The digested energy of CM likewise SBM is an important reason to improve the performance in ruminants. As has been argued previously in the specific case of the comparison between CM and SBM, the form of the camelina, chemical oil extraction process and the type of degradation of $\mathrm{CM}$ in vitro or in situ could modify the rumen fermentation and alter the degradation.

There is lack of evidence concerning the effect of $\mathrm{CM}$ on ruminal $\mathrm{OM}$ and $\mathrm{ME}$ degradation as well as methane emission can be explained by the fact that just maintained in vitro method in the present study. One reason might be the relationship of oil extraction way in feedstuffs and the conditions during the in vitro trial such as bag characteristics, incubation condition in the rumen. The possible effect that there is lack of in vitro investigation that will support the microbial fermentation characteristics of $\mathrm{CM}$ cannot be excluded.

\section{Conclusion}

The results of the present study showed that replacing a proportion of SBM with $\mathrm{CM}$ in an in vitro rumen fermentation can increase the proportion of acetate and total VFA and decrease the methane production whereas the total gas volume was not affected. The other fermentation characteristics and the estimated degradation of ME and OM were not altered. Thus, we considered that $\mathrm{CM}$ can be replaced by SBM, when used as a main protein source in isocaloric and isonitrogenous diets. Thereby, $\mathrm{CM}$ could be an alternative protein source for ruminant diets.

\section{Conflict of Interest}

The authors declare no conflict of interest.

\section{References}

Abdl-Rahman, M. A. (2010). In vitro Manipulation of Rumen Fermentation Efficiency by Fumaric acid - Bentonite Coupled Addition as an Alternative to Antibiotics. Journal of Agricultural Science, 2(2), p174. https://doi.org/10.5539/jas.v2n2p174

Alves, F. J. L., Ferreira, M. de A., Urbano, S. A., de Andrade, R. de P. X., da Silva, Á. E. M., de Siqueira, M. C. B., ... Silva, J. D. L. (2016). Performance of lambs fed alternative protein sources to soybean meal. Revista Brasileira de Zootecnia, 45(4), 145-150. https://doi.org/10.1590/S1806-92902016000400001

Bayat, A. R., Kairenius, P., Stefański, T., Leskinen, H., ComtetMarre, S., Forano, E., ... Shingfield, K. J. (2015). Effect of camelina oil or live yeasts (Saccharomyces cerevisiae) on ruminal methane production, Rumen fermentation, And milk fatty acid composition in lactating cows fed grass silage diets. Journal of Dairy Science, 98(5), 3166-3181. https://doi.org/10.3168/jds.2014-7976

Brandao, V. L. N., Silva, L. G., Paula, E. M., Monteiro, H. F., Dai, X., Lelis, A. L. J., ... Faciola, A. P. (2018). Effects of replacing canola meal with solvent-extracted camelina meal on microbial fermentation in a dual-flow continuous culture system. Journal of Dairy Science, 101(10), 9028-9040. https://doi.org/10.3168/jds.2018-14826

Chaney, A. L., Marbach, E. P. (1962). Modified reagents for determination of urea and ammonia. Clinical Chemistry, 8(2), 130-132.

Colombini, S., Broderick, G. A., Galasso, I., Martinelli, T., Rapetti, L., Russo, R., \& Reggiani, R. (2014). Evaluation of Camelina sativa (L.) Crantz meal as an alternative protein source in ruminant rations. Journal of the Science of Food and Agriculture, 94(4), 736-743. https://doi.org/10.1002/jsfa.6408

Ebeid, H. M., Hassan, F., Li, M., Peng, L., Peng, K., Liang, X., \& Yang, C. (2020). Camelina sativa L. Oil Mitigates Enteric in vitro Methane Production, Modulates Ruminal Fermentation, and Ruminal Bacterial Diversity in Buffaloes. Frontiers in Veterinary Science, 7, 550. https://doi.org/10.3389/fvets.2020.00550

Florou-Paneri, P., Christaki-Sarikaki, E., Peng, J., Tsinas, A., Skoufos, I., Bonos, E., ... Tzora, A. (2014). Alternative protein sources to soybean meal in pig diets. Journal of Food, Agriculture \&amp; Environment, 12, 655660. https://doi.org/10.1234/4.2014.5214

Geissler, C., Hoffmann, M., Hickel, B. (1976). Gas chromatographic estimation of volatile fatty acids. Archives of Animal Nutrition, 26, 123-129.

Haddad, S. G. (2006). Bitter vetch grains as a substitute for soybean meal for growing lambs. Livestock Science, 99(2-3), 221-225. https://doi.org/10.1016/ 
j.livprodsci.2005.06.014

Halmemies-Beauchet-Filleau, A., Shingfield, K. J., Simpura, I., Kokkonen, T., Jaakkola, S., Toivonen, V., \& Vanhatalo, A. (2017). Effect of incremental amounts of camelina oil on milk fatty acid composition in lactating cows fed diets based on a mixture of grass and red clover silage and concentrates containing camelina expeller. Journal of Dairy Science, 100(1), 305-324. https://doi.org/10.3168/jds.2016-11438

Hao, X. Y., Yu, S. C., Mu, C. T., Wu, X. D., Zhang, C. X., Zhao, J. X., \& Zhang, J. X. (2020). Replacing soybean meal with flax seed meal: Effects on nutrient digestibility, rumen microbial protein synthesis and growth performance in sheep. Animal, 14(9), 1841-1848. https://doi.org/ 10.1017/S1751731120000397

Lawrence, R. D., Anderson, J. L., \& Clapper, J. A. (2016). Evaluation of camelina meal as a feedstuff for growing dairy heifers. Journal of Dairy Science, 99(8), 62156228. https://doi.org/10.3168/jds.2016-10876

Menke, H.H. \& Steingass, H. (1988). Estimation of the energetic feed value obtained from chemical analysis and in vitro gas production using rumen fluid. Animal Research and Development, 28, 7-55. Retrieved from https://ci.nii.ac.jp/naid/10025840911

Moriel, P., Nayigihugu, V., Cappellozza, B. I., Gonçalves, E. P., Krall, J. M., Foulke, T., ... Hess, B. W. (2011). Camelina meal and crude glycerin as feed supplements for developing replacement beef heifers. Journal of Animal Science, 89(12), 4314-4324. https://doi.org/10.2527/jas.2010-3630

Paula, E. M., da Silva, L. G., Brandao, V. L. N., Dai, X., \& Faciola, A. P. (2019, October 1). Feeding canola, camelina, and carinata meals to ruminants. Animals, Vol. 9, p. 704. MDPI AG. https://doi.org/10.3390/ani9100704

Russo, R., \& Reggiani, R. (2017). Glucosinolates and Sinapine in Camelina Meal. Food and Nutrition Sciences, 08(12), 1063-1073. https://doi.org/10.4236/fns.2017.812078
Salas, H., Castillejos, L., López-Suárez, M., \& Ferret, A. (2019). In Vitro Digestibility, In Situ Degradability, Rumen Fermentation and $\mathrm{N}$ Metabolism of Camelina CoProducts for Beef Cattle Studied with a Dual Flow Continuous Culture System. Animals, 9(12), 1079. https://doi.org/10.3390/ani9121079

Sizmaz, O., Calik, A., Sizmaz, S., \& Yildiz, G. (2016). A comparison of camelina meal and soybean meal degradation during incubation with rumen fluid as tested in vitro. Ankara Üniversitesi Veteriner Fakültesi Dergisi, 63, 157-161.

Vincent, I. C., Hill, R., \& Williams, H. L. (Dep. V. M. and A. H. T. R. V. C. B. P. P. B. H. E. 1NB (UK)). (1988). Rapeseed meal in the diet of pubertal heifers during early pregnancy. Animal Production (UK). Retrieved from https://agris.fao.org/agris-search/search.do?recordID $=\mathrm{GB} 8901689$

Wang, S., Kreuzer, M., Braun, U., \& Schwarm, A. (2017). Effect of unconventional oilseeds (safflower, poppy, hemp, camelina) on in vitro ruminal methane production and fermentation. Journal of the Science of Food and Agriculture, 97(11), 3864-3870. https://doi.org/ 10.1002/jsfa.8260

Waraich, E. A., Ahmed, Z., Ahmad, R., Yasin Ashraf, M., Saifullah, Naeem, M. S., \& Rengel, Z. (2013). Camelina sativa, a climate proof crop, has high nutritive value and multiple-uses: A review. Australian Journal of Crop Science, 7(10), 1551-1559.

Wolin, M. J. (1960). A theoretical rumen fermentation balance. Journal of Dairy Science, 43(10), 1452-1459. https://doi.org/10.3168/jds.S0022-0302(60)90348-9

Zagorakis, K., Liamadis, D., Milis, C., Dotas, V., Dotas, D. (2015). Nutrient digestibility and in situ degradability of alternatives to soybean meal protein sources for sheep. Small Ruminant Research, 124, 38-44. 